\title{
Litigation shadows Marseille's biotech center
}

Major and potentially protracted legal proceedings currently stand between Marseille in the south of France and its ambitions to become a center for biotechnology. Representatives of the city want to begin a series of visits to North America to promote the city to medium-sized companies interested in having a presence in Europe. But until an earlier dispute is resolved, that cannot happen.

The litigation stems from an earlier, 1993 attempt to attract biotechnology companies to Marseille. That grandiose scheme, known as Cité de la Biotique, had as its centerpiece a 3.5 hectare city center site that was to be the location of a concentrated commercial "biological reactor," the Villa Hippocrate. All that remains now of the Villa Hippocrate-indeed all that ever existedis a rather handsome brochure published in 1993 and a conspicuously underdeveloped plot of prime real estate. That site still has considerable value, of course, and now two of the main protagonists of the Cité de la Biotique-the powerful public hospital system of Marseille (APM) and a private real estate developer, $\mathrm{CBC}$, which is a subsidiary of the French construction conglomerate, La Société Générale des Eaux-are both claiming ownership of the site.

The Cité de la Biotique was originally the idea of Georges Mehrle, who was head of APM when the project started. APM, together with the Marseille Chamber of Commerce, were looking for an extra source of revenue for the city's health-care system. The core of the project involved bringing together two of Marseille's largest public hospitals, the schools of medicine, pharmacy and dentistry of the University of Aix-Marseille, and

Anthony Molloy is a freelance writer working in Marseille, France. constructing the Villa Hippocrate to provide laboratory and office space for private biotechnology companies.

As early as 1994, the project was obviously foundering. There were two major problems with the scheme. First, it was extravagant. The Villa Hippocrate was to be a $60,000 \mathrm{~m}^{2}$ development, bringing together public and private health and life science came primarily because the APM was prepared to facilitate the company's access to the financial incentives offered by the various city, regional, national, and European administrations.

The new administration at APM will not comment on the old project. Michel Delaage, founder of Immunotech, a Marseille-based supplier of monoclonal antibodies worldwide [and now part of Coulter (Miami, FL)], believes that a major fault in the way the project was conceived was that the private sector was minimally involved in its design. The financial incentives and research and clinical development opportunities were, and are, attractive for biotechnology companies. But the Villa Hippocrate was just a real estate program. Even had the building actually existed, it would have been too expensive, especially for prospective clients like biotechnology companies for whom prestigious

esearch and development activities. According to Olivier Latil d'Albertas, Marseille's current economic affairs director, the idea was "extremely ambitious." It was abandoned for legal and market reasons, he says, adding that "It was never realistic to imagine attracting enough companies to fill $60,000 \mathrm{~m}^{2}$."

The other problem was that companies had to commit themselves to taking expensive space in the Villa Hippocrate, a building that did not exist. In the meantime, they were offered temporary facilities elsewhere in the region. Among the biotechnology companies approached, which included Systemix (Palo Alto, CA) and Somatix Therapy (Alameda, CA), only Genta (San Diego, CA) made a firm commitment. Even for Genta, the Villa Hippocrate was a disincentive, according to Guy van de Winckel, the head of Genta's Marseille office: The company premises are a low priority.

Marseille's potential as a center for biotechnology has been set back several years as a result of this ill-conceived scheme. Mehrle moved to the Ministry of Health and Social Security in Paris in 1995. But perhaps lessons have been learned. The Cité de la Biotique project has been reformulated, stripped of the real estate elements of the old scheme, and stripped of any involvement from APM. The current scheme relies on existing premises in and around Marseille, and although plans for the Villa Hippocrate have not disappeared completely, they are scaled down considerably-from 60,000 to $4,000 \mathrm{~m}^{2}$.

Anthony Molloy 